Selcuk Journal of Agriculture and Food Sciences

http://sjafs.selcuk.edu.tr/sjafs/index

Research Article
SJAFS

(2019) 33 (2), 106-113

e-ISSN: 2458-8377

DOI: $10.15316 /$ SJAFS.2019.164

\title{
Effects of Bacteria and IBA on the Rooting of Bitter Orange (Citrus aurantium L.) and Trifoliate Orange (Poncirus trifoliata Raf.) Cuttings
}

\author{
Mustafa ÇINAR ${ }^{1}$, Lütfi PIRLAK ${ }^{2 *}$, Güçer KAFA ${ }^{3}$, Metin TURAN ${ }^{4}$ \\ ${ }^{1}$ Directorate of Agricultural Production Enterprise, Agricultural Extension and In-Service Training Center, Adana, \\ Turkey \\ ${ }^{2}$ Selçuk University, Faculty of Agriculture, Department of Horticulture, Konya, Turkey \\ ${ }^{3}$ Alata Horticultural Research Institute, Erdemli, Mersin, Turkey \\ ${ }^{4}$ Yeditepe University Faculty of Engineering, Department of Genetics and Bioengineering, İstanbul, Turkey
}

\begin{tabular}{l}
\hline ARTICLE INFO \\
\hline Article history: \\
Received date: 24.05 .2019 \\
Accepted date: 11.06 .2019 \\
\hline Edited by: \\
Ali SABIR; Selçuk University, Turkey \\
Reviewed by: \\
Halil İbrahim OĞUZ; Nevşehir Hact \\
Bektaş Veli University, Turkey \\
Ümmügülsüm ERDOĞAN; Bayburt \\
University, Turkey \\
\hline
\end{tabular}

Keywords:

Bitter orange

Trifoliate orange

IBA

Plant growth promoting bacteria

Rooting of cutting

\begin{abstract}
In this study, the effects of Agrobacterium rubi A-18 and Bacillus OSU-142 bacterial strains alone and in combination with 1000, 2000, $4000 \mathrm{ppm}$ IBA on rooting of bitter orange and trifoliate orange citrus rootstock in softwood, semihardwood and hardwood cuttings were investigated. In the case of IBA solution, Agrobacterium rubi A-18 and Bacillus OSU-142 were prepared in solution at a concentration of $1 \times 10^{9}$ bacteria / $\mathrm{ml}$ and applied to steel. Application is made in the mist propagation system, in the perlite are planted in the environment. Steels kept in the fogging environment for 3 months were removed at the end of this period and rooting rates (\%), callus formation rates $(\%)$ and survival rates $(\%)$ were determined. According to the results of the research, the rooting rates of the steels taken at different periods were found to be low. The highest rooting rates of bitter orange softwood cuttings were $2000 \mathrm{ppm}$ IBA + OSU-142 (6.67\%), semi-hardwood cuttings OSU-142 (20.00\%), and 4000 ppm IBA + OSU-142 (20.00\%) in hardwood cuttings. It has been not rooting in trifoliate orange softwood cuttings, the highest rooting was in the case of semi-hardwood cuttings with 4000 ppm IBA + OSU-142 (26.67\%), in hardwood cuttings 1000 ppm IBA + OSU-142, 2000 ppm IBA + OSU-142, 4000 ppm IBA + OSU-142, 1000 ppm IBA + A-18, 2000 ppm IBA + A-18 and $4000 \mathrm{ppm} \mathrm{IBA}+\mathrm{A}-18(20.00 \%)$. According to the cuttings pick-up period, the rooting rates of bitter orange are not different between the periods, in the trifoliate orange the hardwood cuttings were found to be higher. As a result, it can be said that plant growth promoting bacteria and IBA applications have no effect on rooting in the softwood, semi-hardwood and hardwood cuttings of the bitter orange and trifoliate orange citrus rootstocks, it can be said that studies on rooting in these rootstocks can be useful in different bacterial breeds
\end{abstract}

\section{Introduction}

Turkey is one of the rare countries where a combination of many types of fruit grown in the world. At present, Turkey is one of the most important producers of many fruit species besides being one of the most production of some fruit species in the world.

Citrus fruit is a young plant group. This group includes the species of citrus, which has a high economic value such as orange, mandarin, bergamot, grapefruit and lemon. They are produced economically and are extremely important for human health. Citrus fruits, which are considered as vitamin depots of winter months, are consumed widely as fruit juice besides their fresh consumption. As used in the fruits of these plants, fruit oils, leaves or flowers perfume fragrance used to give the essential oils are obtained. The production of citrus fruits grown between 40 degrees north latitude and 40 degrees south latitude in the world is continuously increasing.

Citrus fruits are native to China, Southeast Asia and India and can grow in tropical and subtropical climates. However, it is possible to grow commercially in regions where the temperature does not fall below $-4^{\circ} \mathrm{C}$.

In Turkey, reaching about 5 million tons of citrus is done in coastal areas of the Mediterranean and Aegean regions of production. In Turkey, the most grown fruits after apples and grapes are also citrus fruits. Commercial sense in the production of Turkey is examined, as

\footnotetext{
* Corresponding author email: pirlak@selcuk.edu.tr
} 
well as most types of citrus produced in the world, respectively, orange, mandarin, lemon and grapefruit.

The cultivation of citrus fruit, whose homeland is Southeast Asia, began in the US in the modern sense in the 19th century and spread rapidly. In the Northern Hemisphere, North and Central America and the Mediterranean countries are produced economically in the Southern Hemisphere, South America, South Africa and Oceania. The largest citrus producer countries in the world; Brazil, USA and China. Turkey is among the first 10 countries in the world citrus production (FAO, 2019).

Turkey is located in the northern border areas of the world citrus production. Which is quite old with a history of citrus production in Turkey after to develop rapidly and has been a significant increase in production from 1930. Turkey has very suitable areas for citrus cultivation in terms of ecological conditions. Turkey's amount of citrus production data for 2017 is 4 million 769 thousand 772 tons (TUIK, 2019).

The prevalence of foreign fertilization has led to vegetative propagation methods in many fruit species and varieties. Thus, it is possible to prevent the openings resulting from seed reproduction and to protect all the features of the variety. In vegetative reproduction; steel, dipping, root and bottom shoots or tubers with one or more of the replication methods are used, but in today's fruit, especially the method of reproduction with vaccination is more widely used (Rom, 1987; Hartmann, et al., 1990).

In the production of citrus species such as other fruit species, seed reproduction is not used directly. Since cuttings reproduction is not very successful in these species, the basis of production is based on reproduction. It is based on cultivation of different plants such as reproduction rootstock and scion on the same body. There are two elements, namely rootstock and scion, for reproduction. While the scion forms the crown of the tree, it forms the subsoil part of the rootstock tree and assists in the holding and transport of water and nutrients. Rootstocks in fruit cultivation are as important as the varieties that are inoculated on them. As a matter of fact, although a fruit rootstock is not expected to have the characteristics of a standard variety, rootstocks must have a good performance in the subsoil and special relations formed by the scion. The living part that undertakes primary responsibility in the life of the trees is the roots. Their relationship with the environment in which they spread in the soil is important in terms of the effect of the trees on their being healthy and efficient. In recent years, changes in fruit growing methods are possible with the use of appropriate rootstocks (Gülcan, 1991).

Rootstocks are classified as generative and vegetative rootstocks according to their production methods. Because of the generative way of opening up seed and rootstock production, rapid increase in the use of clone rootstocks has occurred in the production of fruit saplings in recent years. In the production of citrus fruit species, the use of clone rootstocks is becoming increasingly common in order to increase yield and quality and to provide tolerance for many abiotic and biotic stresses. The most common use of clonal rootstocks in the world is in citrus fruits.

Rootstocks used in fruit growing are divided into slices and clone rootstocks. In most of the fruit species, seedling rootstocks are used. The common drawback of almost all of them is that they show too many variations. This negatively affects the homogeneity of the development of the tree. Furthermore, it is known that heterogeneous developing seedlings have different behaviors in terms of rootstock mismatch and adaptation to the environment (Gülcan, 1991). Due to the opening in the seeds, seed levels on seedling rootstocks, growth forces, productivity, fruit characteristics, drought, cold, disease and pest resistance levels are heterogeneous and constitute the most important disadvantages of these rootstocks.

Different rootstocks are used in citrus sapling production. The most important ones are bitter orange and hybrids, trifoliate orange and hybrids, mandarin and mandarin analogues, lemons and relatives, limes and relatives, orange, citremon (trifoliate orange $\mathrm{X}$ lemon), citrumelo (trifoliate orange X grapefruit), sweet laym, grapefruit, yuzu, volkameriana, macrophylla, sitranges (trifoliate orange $\mathrm{X}$ oranges). Among these rootstocks, the most commonly used in Turkey are bitter orange and trifoliate orange (Mendilcioglu, 1999).

Bitter orange and trifoliate orange is used as rootstock for citrus experiencing difficulties of rooting cuttings. To solve the problem of rooting, indole acetic acid (De Klerk et al., 1997, Ahmad et al., 2005), some vitamins (Antonopoulou et al., 2005) are made such applications. In addition, it has been reported in many studies that it has recently been introduced as a solution to the problem of rooting with rhizobacteria that increase plant growth which has recently become widespread (Bassil et al., 1991; Larraburu et al., 2007; Teixeira et al., 2007; Ertürk et al., 2011; Arıkan et al., 2013).

In this study, the effects of Bacillus OSU-142 and Bacillus A-18 bacterial strains and indole butyric acid (IBA) applications were investigated on rootstocks of bitter orange and trifoliate orange, which are widely used as rootstock in citrus fruits.

\section{Materials and Methods}

This study was conducted between 2017 and 2018 in a heated greenhouse in Directorate of Agricultural Production Enterprise, Agricultural Extension and InService Training Center, Adana.

\section{Materials}

In this study, bitter orange (Citrus aurantium L.) and trifoliate orange (Poncirus trifoliata) rootstocks were used as materials. The citrus cuttings used in the study were obtained from Alata Horticultural Research Institute, Mersin. 
Bitter orange (Citrus aurantium L.) has been the most widely used rootstock for oranges, mandarins, lemons and grapefruit in Mediterranean basin and other citrus producers countries. Bitter orange is widely used in heavy, drainage-poor soils because it shows moderate resistance to high soil $\mathrm{pH}$. Bitter orange can grow on heavy soils, it is resistant to lime and tends to make pile root. Some lemon varieties and satsuma generally show good agreement with species and varieties other than mandarin. Trees grafted on bitter orange form a standard size crown. It is widely used in all Mediterranean regions. Easy to propagation. It is sensitive to the diseases of tristeza and mal-secco. Dwarfing is resistant to pore virus disease and root collar rot. Good resistance to frost. As it forms deep roots, it has good resistance to drought (Mendilcioğlu, 1999).

Trifoliate orange (Poncirus trifoliata Raf.) is a rootstock that shed its leaves in subtropic conditions. One of the important features is that it is cold resistant. The trifoliate orange tree is placed on the early fruit and affects the fruit quality in a positive way. Aegean and the eastern Black Sea region of Turkey is used as rootstock mandarin. Winter rootstocks are the most rootstocks. Resistant to root collar rot. Provides early yield. It is a suitable rootstock for orange and satsuma. It is not good to correspond with lemons, especially Kütdiken. Calcareous and salty soils can not withstand (Mendilcioglu, 1999).

In this study, Agrobacterium rubi A-18 and Bacillus OSU-142 bacterial strains which were determined to produce auxin by in vitro studies were used. Bacteria were obtained from Yeditepe University Faculty of Engineering, Department of Genetics and Bioengineering.

\section{Methods}

Cuttings from citrus rootstocks were prepared as softwood in July (2017), semi - hardwood in October (2017) and hardwood in January (2018). The cuttings used in the research were obtained from the trees from the Alata Horticultural Research Institute, Mersin. Cuttings are prepared with 4 leaves, 2 leaves-free, top 2 leaves were planted. These cuttings alone and in combination with 1000, 2000 and 4000 ppm IBA Agrobacterium rubi A-18 and Bacillus OSU-142 bacterial strains were applied. Applications to cuttings are given below.

\section{Control}

2. 1000 ppm IBA

3. 2000 ppm IBA

4. $4000 \mathrm{ppm}$ IBA

5. OSU- 142

6. A-18

7. OSU- $142+\mathrm{A}-18$

8. 1000 ppm IBA + OSU-142

9. 2000 ppm IBA + OSU-142

10. 4000 ppm IBA + OSU-142

11. 1000 ppm IBA + A-18

\section{2. $2000 \mathrm{ppm}$ IBA + A-18}

13. 4000 ppm IBA + A-18

Prepared cuttings was prepared by rapid immersion in IBA solution and bacterial strains were prepared in suspension at a concentration of 1x109 bacteria / ml (Purlak and Baykal, 2011). The applied cuttings were placed in the mist prooagation unit with temperature of $25^{\circ} \mathrm{C}, 90-95 \%$ relative humidity and perlite. Cuttings held in the mist propagation environment for about 3 months were removed at the end of this period, rooting rates $(\%)$, callus formation rates $(\%)$ and survival rates (\%) were detected (Bhusal et al., 2001). While the survival rates of the stripped cuttings were determined, it was examined whether the tissue beneath the steel shells were alive and also the sections were taken from the eyes on the steel and these eyes were considered alive when they kept the green color.

\section{Statistical Analysis}

Trial; two factors (applications, cuttings retrieval period) according to the her competely randomized design, three replicates and 5 steel in each repetition have been established. The data obtained were subjected to arc sinus (angle) transformation and evaluated by SPSS statistical program and Duncan Multiple Comparison Test was applied.

\section{Results and Discussion}

\section{The effects of applications on the cutting rooting of bitter orange}

The effects of plant growth promoting bacteria and IBA applications on the rooting of softwood, semihardwood and hardwood cuttings in bitter orange were found to be statistically significant (Table 1). During the rooting period, most of the softwood cuttings were unable to maintain its viability. In the control application, the viability ratio decreased by $33.33 \%$ compared to the control in most of the applications, and the viability rates were higher in the 1000 ppm IBA + OSU-142 $(40 \%)$ and 2000 ppm IBA + OSU-142 (53.33\%) applications. The lowest viability rates were found in $13.33 \%$ and 4000 ppm IBA and OSU-142 applications. In parallel with the viability rates, the callus formation ratio in softwood cutting is also low. The callus formation rate, which was $13.33 \%$ in the control, decreased to $6.67 \%$ in the $4000 \mathrm{ppm}$ IBA application and in the other applications was the same or higher than the control. The highest callus formations were $1000 \mathrm{ppm}$ IBA + OSU-142 and 4000 ppm IBA + A-18 (33.33\%) and 2000 ppm IBA + OSU-142 (53.33\%). The applications did not have a positive effect on rooting in softwood cuttings, but only in 2000 ppm IBA + OSU142 rooting $6.67 \%$.

Most of the semi-hardwood cuttings remained alive in the rooting environment. In most of the applications, the viability rate was found to be $100 \%$ and only $80 \%$ in OSU-142 application was statistically different from other applications (Table 1). Similarly, callus formation is also high in semi-hardwood cuttings. The hig- 
hest callus formation occurred in 1000 ppm IBA and OSU-142 + A-18 (100\%) and the lowest in $2000 \mathrm{ppm}$ and 4000 ppm IBA applications (73.33\%). Although the viability and callus ratios were high in semihardwood steels, no rooting occurred in applications other than OSU-142 (20\%).

The viability rates of hardwood steels were generally low. While all of the cuttings were dying, viability rates increased slightly due to bacterial and IBA applications except 1000 ppm IBA and 4000 ppm IBA + A18. Differences between applications are statistically significant. The highest viability rates were found in 4000 ppm IBA + OSU-142 and 1000 ppm IBA + A-18 applications (53.33\%). Callus formation is also low in hardwood cuttings. Similar to the viability rates, callus did not occur in the control and the callus ratios increased slightly due to the applications other than 1000 ppm IBA and 4000 ppm IBA + A-18. The most effective applications on callus formation were $4000 \mathrm{ppm}$ IBA + OSU-142 and 1000 ppm IBA + A-18 (40.00\%). Rooting rates in hardwood cuttings have not reached satisfactory levels. While rooting did not occur in the Table 1

The effects of applications on the cutting rooting of bitter orange control application, slaughtering effects of bacteria and IBA applications were limited and low rates of rooting occurred in only 5 applications. The highest rooting rate was 4000 ppm IBA + OSU-142 with a rate of $20.00 \%$ (Table 1).

When the effects of bacterial and IBA applications on citrus rootstock according to steel intake periods are examined, it is seen that the differences between the effects of the applications on the viability and callus formation are statistically significant and the effects on rooting are insignificant (Table 1). There are big differences in the vitality rates of steels according to periods. The highest viability ratio was obtained in semihardwood cuttings $(96.41 \%)$, followed by softwood (27.69\%) and hardwood cuttings (19.49\%). Similarly, in the callus ratios, semi-hardwood cuttings are higher than others $(89.23 \%)$. The callus ratio was found to be $21.54 \%$ in softwood cuttings and $16.92 \%$ in hardwood cuttings. At the time of the three cuttings pick-ups, rooting rates were very low and no statistical difference was found between the periods.

\begin{tabular}{|c|c|c|c|c|c|c|c|c|c|}
\hline & \multicolumn{9}{|c|}{ BITTER ORANGE } \\
\hline & \multicolumn{3}{|c|}{ SOFTWOOD CUTTINGS } & \multicolumn{3}{|c|}{ SEMI-HARDWOOD CUTTINGS } & \multicolumn{3}{|c|}{ HARDWOOD CUTTINGS } \\
\hline & $\begin{array}{l}\text { Viability } \\
\text { rate }(\%)^{*}\end{array}$ & $\begin{array}{l}\text { Callus forma- } \\
\text { tion rate }(\%)\end{array}$ & $\begin{array}{l}\text { Rooting } \\
\text { rate }(\%)\end{array}$ & $\begin{array}{l}\text { Viability } \\
\text { rate }(\%)\end{array}$ & $\begin{array}{l}\text { Callus forma- } \\
\text { tion rate }(\%)\end{array}$ & $\begin{array}{l}\text { Rooting } \\
\text { rate }(\%)\end{array}$ & $\begin{array}{l}\text { Viability } \\
\text { rate }(\%)\end{array}$ & $\begin{array}{c}\text { Callus forma- } \\
\text { tion rate }(\%)\end{array}$ & $\begin{array}{l}\text { Rooting } \\
\text { rate }(\%)\end{array}$ \\
\hline Control & $\begin{array}{l}33.33 \\
a b * *\end{array}$ & $13.33 \mathrm{bc}$ & $0.00 \mathrm{~b}$ & $100.00 \mathrm{a}$ & $86.67 \mathrm{abc}$ & $0.00 \mathrm{~b}$ & $0.00 \mathrm{c}$ & $0.00 \mathrm{c}$ & $0.00 \mathrm{~b}$ \\
\hline $\begin{array}{l}1000 \mathrm{ppm} \\
\text { IBA }\end{array}$ & $26.67 \mathrm{bc}$ & $26.67 \mathrm{ab}$ & $0.00 \mathrm{~b}$ & $100.00 \mathrm{a}$ & $100.00 \mathrm{a}$ & $0.00 \mathrm{~b}$ & $0.00 \mathrm{c}$ & $0.00 \mathrm{c}$ & $0.00 \mathrm{~b}$ \\
\hline $\begin{array}{l}2000 \mathrm{ppm} \\
\text { IBA }\end{array}$ & $26.67 \mathrm{bc}$ & $26.67 \mathrm{ab}$ & $0.00 \mathrm{~b}$ & $100.00 \mathrm{a}$ & $73.33 \mathrm{c}$ & $0.00 \mathrm{~b}$ & $20.00 \mathrm{~b}$ & $20.00 \mathrm{ab}$ & $0.00 \mathrm{~b}$ \\
\hline $\begin{array}{l}4000 \mathrm{ppm} \\
\text { IBA }\end{array}$ & $13.33 \mathrm{c}$ & $6.67 \mathrm{c}$ & $0.00 \mathrm{~b}$ & $100.00 \mathrm{a}$ & $73.33 \mathrm{c}$ & $0.00 \mathrm{~b}$ & $26.67 \mathrm{~b}$ & $26.67 \mathrm{a}$ & $6.67 \mathrm{~b}$ \\
\hline OSU-142 & $13.33 \mathrm{c}$ & $13.33 \mathrm{bc}$ & $0.00 \mathrm{~b}$ & $80.00 \mathrm{~b}$ & $80.00 \mathrm{bc}$ & $20.00 \mathrm{a}$ & $20.00 \mathrm{~b}$ & $20.00 \mathrm{ab}$ & $0.00 \mathrm{~b}$ \\
\hline A-18 & $20.00 \mathrm{bc}$ & $20.00 \mathrm{bc}$ & $0.00 \mathrm{~b}$ & $93.33 \mathrm{a}$ & $86.67 \mathrm{abc}$ & $0.00 \mathrm{~b}$ & $20.00 \mathrm{~b}$ & $20.00 \mathrm{ab}$ & $0.00 \mathrm{~b}$ \\
\hline $\begin{array}{l}\text { OSU+A-18 } \\
1000 \mathrm{ppm}\end{array}$ & $26.67 \mathrm{bc}$ & $13.33 \mathrm{bc}$ & $0.00 \mathrm{~b}$ & $100.00 \mathrm{a}$ & $100.00 \mathrm{a}$ & $0.00 \mathrm{~b}$ & $13.33 \mathrm{~b}$ & $6.67 \mathrm{~cd}$ & $0.00 \mathrm{~b}$ \\
\hline $\begin{array}{l}\text { IBA+OSU- } \\
142\end{array}$ & $40.00 \mathrm{ab}$ & $33.33 \mathrm{ab}$ & $0.00 \mathrm{~b}$ & $100.00 \mathrm{a}$ & $93.33 \mathrm{ab}$ & $0.00 \mathrm{~b}$ & $13.33 \mathrm{~b}$ & $13.33 \mathrm{bc}$ & $6.67 \mathrm{~b}$ \\
\hline $\begin{array}{l}2000 \mathrm{ppm} \\
\text { IBA+OSU- } \\
142\end{array}$ & $53.33 \mathrm{a}$ & $53.33 \mathrm{a}$ & $6.67 \mathrm{a}$ & $93.33 \mathrm{a}$ & $93.33 \mathrm{ab}$ & $0.00 \mathrm{~b}$ & $13.33 \mathrm{~b}$ & $13.33 \mathrm{bc}$ & $0.00 \mathrm{~b}$ \\
\hline $\begin{array}{l}4000 \mathrm{ppm} \\
\text { IBA+OSU- } \\
142\end{array}$ & $26.67 \mathrm{bc}$ & $13.33 \mathrm{bc}$ & $0.00 \mathrm{~b}$ & $100.00 \mathrm{a}$ & $93.33 \mathrm{ab}$ & $0.00 \mathrm{~b}$ & $53.33 \mathrm{a}$ & $40.00 \mathrm{a}$ & $20.00 \mathrm{a}$ \\
\hline $\begin{array}{l}1000 \text { ppm } \\
\text { IBA +A-18 }\end{array}$ & $20.00 \mathrm{bc}$ & $13.33 \mathrm{bc}$ & $0.00 \mathrm{~b}$ & $93.33 \mathrm{a}$ & $93.33 \mathrm{ab}$ & $0.00 \mathrm{~b}$ & $53.33 \mathrm{a}$ & $40.00 \mathrm{a}$ & $6.67 \mathrm{~b}$ \\
\hline $\begin{array}{l}2000 \text { ppm } \\
\text { IBA +A-18 }\end{array}$ & $26.67 \mathrm{bc}$ & $13.33 \mathrm{bc}$ & $0.00 \mathrm{~b}$ & $100.00 \mathrm{a}$ & $93.33 \mathrm{ab}$ & $0.00 \mathrm{~b}$ & $20.00 \mathrm{~b}$ & $20.00 \mathrm{ab}$ & $6.67 \mathrm{~b}$ \\
\hline $\begin{array}{l}4000 \mathrm{ppm} \\
\text { IBA +A-18 }\end{array}$ & $33.33 \mathrm{ab}$ & $33.33 \mathrm{ab}$ & $0.00 \mathrm{~b}$ & $93.33 \mathrm{a}$ & $93.33 \mathrm{ab}$ & $0.00 \mathrm{~b}$ & $0.00 \mathrm{c}$ & $0.00 \mathrm{c}$ & $0.00 \mathrm{~b}$ \\
\hline LSD & 19.63 & 28.72 & 10.09 & 20.18 & 26.35 & 20.18 & 19.6 & 18.13 & 21.25 \\
\hline
\end{tabular}


Table 1 (Continuation)

The effects of applications on the cutting rooting of bitter orange

\begin{tabular}{lccc}
\hline & Viability rate $(\%)$ & Callus formation rate $(\%)$ & Rooting rate $(\%)$ \\
\hline SOFTWOOD CUTTINGS & $27.69 \mathrm{~b}$ & $21.54 \mathrm{~b}$ & 0.51 \\
SEMI-HARDWOOD CUTTINGS & $96.41 \mathrm{a}$ & $89.23 \mathrm{a}$ & 1.54 \\
HARDWOOD CUTTINGS & $19.49 \mathrm{c}$ & $16.92 \mathrm{~b}$ & 3.59 \\
LSD & 11.26 & 13.17 & O.D. \\
\hline
\end{tabular}

*Statistical analysis have been carried out using arc sin values.

** Values shown in different letters in the same column are different at 0.05 (Duncan test)

\section{The effects of applications on cutting rooting of trifoli- ate orange}

The effects of plant growth promoting bacteria and IBA applications on the rooting of softwood, semihardwood and hardwood cuttings with trifoliate orange rootstock are given in Table 2 . The effects of applications on viability, callus formation and rooting were found to be statistically significant.

Trifoliate orange softwood cuttings showed low viability at the end of rooting time. The differences between the effects of the applications on the viability of softwood cuttings were not statistically significant. Similarly, callus formation rates in softwood cuttings are also low. In the control group, no callus was formed in the cuttings, but in some applications a low callus was formed. The maximum callus formation was determined as $20.00 \%$ in 2000 ppm IBA + OSU-142 and $13.33 \%$ in 4000 ppm IBA + OSU-142 applications. Rooting did not occur in any application, including control in trifoliate orange softwood cuttings.

A large part of the trifoliate orange rootstock semihardwood cuttings kept alive in the rooting environment. The highest viability rates were found to be 1000 ppm IBA (100\%) and control (93.33\%). Similarly, callus formation rates are also high in semi-hardwood cuttings. The highest callus formation rate was found to be 1000 ppm IBA $(100.00 \%)$ and control application $(93.33 \%)$. Although the viability and callus ratios were high in semi-hardwood cuttings, the rooting rates were far behind them. While rooting did not occur in the control, in 6 applications (1000 ppm IBA, $2000 \mathrm{ppm}$ IBA, A-18, OSU-142 + A-18, 2000 ppm IBA + OSU142 and 4000 ppm IBA + OSU-142) rooting at different rates occurred. The maximum rooting was determined as 4000 ppm IBA + OSU-142 with a rate of $20.00 \%$ (Table 2).

The effects of bacterial and IBA applications on the viability of trifoliate orange hardwood cuttings were found to be close to each other. While the effects of all the applications were in the same group with the control, the lowest viability rate was determined as 4000 ppm IBA + OSU-142 with $40.00 \%$ and the highest with $66.67 \%$ and 4000 ppm IBA + A-18. The effects of the applications on the callus formation rate in cuttings are more pronounced than the viability ratios. Callus formation with $26.67 \%$ in the control group, $4000 \mathrm{ppm}$ IBA, A-18, OSU-142 + A-18, 2000 ppm IBA + OSU142, 1000 ppm IBA + A-18, 200 ppm IBA + A-18 and 4000 ppm IBA + A-18 showed a statistically signifi- cant increase compared to the control. The highest callus rate was found in $4000 \mathrm{ppm}$ IBA + A-18 application $(60.00 \%)$. Applications increased the rate of rooting in hardwood cuttings compared to the control except for OSU-142 and OSU-142 + A-18. 20.00\% of the most rooting practices are $1000 \mathrm{ppm}$ IBA + OSU142, 2000 ppm IBA + OSU, 4000 ppm IBA + OSU142, $1000 \mathrm{ppm} \mathrm{IBA}+\mathrm{A}-18,2000 \mathrm{ppm} \mathrm{IBA}+\mathrm{A}-18$ and 4000 ppm IBA + A-18 (Table 2).

The effect of applications on the viability, callus formation and rooting were found to be statistically significant. The viability ratios of the cuttings were found to be significantly different according to the periods and the highest viability was found in semihardwood cuttings $(76.41 \%)$ and the least in softwood cuttings $(8.72 \%)$. The average viability of hardwood cuttings was found to be $52.82 \%$. The highest callus formation was determined in semi-hardwood (75.38\%), followed by hardwood cuttings $(42.56 \%)$ and softwood cuttings $(5.13 \%)$. In rooting rates, hardwood cuttings ranked first with $12.81 \%$, followed by semi-hardwood with $6.67 \%$ and softwood cuttings with $0.00 \%$. A large part of the trifoliate orange rootstock semi-hardwood cuttings kept alive in the rooting environment. The maximum viability rates are 1000 ppm IBA (100\%) and control (93\%).

In this study, the effect of plant growth- promoting bacteria and IBA applications on the rooting of bitter orange and trifoliate orange rootstocks in softwood, semi-hardwood and hardwood cuttings were found to be low. The highest rooting rates were 2000 ppm IBA + OSU-142 (6.67\%), in semi-hardwood cuttings OSU$142(20.00 \%), 4000$ ppm IBA + OSU-142 (20.00\%) in hardwood cuttings; trifoliate orange softwood cuttings, non-rooting, semi-hardwood cutting 4000 ppm IBA + OSU-142 (26.67\%), hardwood cuttings 1000 ppm IBA + OSU-142, 2000 ppm IBA + OSU-142, 4000 ppm IBA + OSU-142, 1000 ppm IBA + A-18 was detected in $2000 \mathrm{ppm} \mathrm{IBA}+\mathrm{A}-18$ and $4000 \mathrm{ppm} \mathrm{IBA}+\mathrm{A}-18$ (20.00\%) applications (Table 1, 2). Similar results were obtained in a study of M9 apple rootstock cuttings and it was determined that bacteria and IBA applications had no effect on rooting (Prrlak and Baykal, 2009).

Due to its many advantages, cutting reproduction is widely used in fruit growing as in most plant species. Among these advantages, a small part of the body in a small area with a large number of homogenous plants, cheap, quick and easy to be counted. Furthermore, in this replication method, soil-borne diseases are less 
likely to cross plants. Despite all the positive properties of cuttings reproduction, the biggest obstacle to its use is the inability of the steel to root due to the very low regeneration capabilities of some species (Rugini and Fedelli, 1990; Webster and Looney, 1996). The low rate of rooting in citrus rootstock cuttings are related to species characteristics. The rooting ability of the cutting in the fruit species varies greatly between different species and varieties within these species. According to this, species are classified as very easily rooted, hardrooted and very hard-rooted. Citrus species in this grouping are often among the hard-rooted (Hartmann, et al., 1990). As a matter of fact, positive results have been obtained in studies that investigated the effects of bacterial applications in genetically rooting species (Nagarajan et al., 1989; Bassil et al., 1991; Jacob and Handam, 1992; Hatta et al., 1996; Ercişli et al., 2000; Ercişli et al., 2001; Eşitken et al., 2001; Ertürk et al.,
2011; Sarmast et al., 2012; Arıkan et al., 2013; Kınık and Çelikel, 2017).

In general, the reproduction of citrus fruits, which are replicated by cuttings, has not been achieved so far except for lemons (Cooper, 1935). In the study which investigated the effects of IBA and Paclobutrazol on the rooting of Valencia orange varieties, the highest rooting (19.6\%) was obtained from 500 ppm IBA + Paclobutrazol application (Habermann et al., 2006). In the study which examined the effects of IBA applications on cutting rooting in different citrus rootstocks, it was not detected in trifoliate orange, Carrizo citrange, Cleopatra mandarin, Citrumelo 1452 rootstocks and rooting in different IBA applications (Uzun and Seday, 2011). The effects of IBA and cycloposphamide on the rooting of rough lemon (Citrus jambhiri) cuttings were examined in the study and the highest rooting rate $(8.2 \%)$ was obtained with the use of IBA and cycloposphamide (Singh et al., 1988).

Table 2

The effects of applications on the cutting rooting of trifoliate orange

\begin{tabular}{|c|c|c|c|c|c|c|c|c|c|}
\hline & \multicolumn{9}{|c|}{ TRIFOLIATE ORANGE } \\
\hline & \multicolumn{3}{|c|}{ SOFTWOOD CUTTINGS } & \multicolumn{3}{|c|}{ SEMI-HARDWOOD CUTTINGS } & \multicolumn{3}{|c|}{ HARDWOOD CUTTINGS } \\
\hline & $\begin{array}{l}\text { Viability } \\
\text { rate }(\%)^{*}\end{array}$ & $\begin{array}{l}\text { Callus forma- } \\
\text { tion rate }(\%)\end{array}$ & $\begin{array}{l}\text { Rooting } \\
\text { rate }(\%)\end{array}$ & $\begin{array}{l}\text { Viability } \\
\text { rate }(\%)\end{array}$ & $\begin{array}{l}\text { Callus forma- } \\
\text { tion rate }(\%)\end{array}$ & $\begin{array}{l}\text { Rooting } \\
\text { rate }(\%)\end{array}$ & $\begin{array}{l}\text { Viability } \\
\text { rate }(\%)\end{array}$ & $\begin{array}{l}\text { Callus forma- } \\
\text { tion rate }(\%)\end{array}$ & $\begin{array}{l}\text { Rooting } \\
\text { rate }(\%)\end{array}$ \\
\hline Control & $6.67 * *$ & $0.00 \mathrm{c}$ & 0.00 & $93.33 \mathrm{ab}$ & $93.33 \mathrm{ab}$ & $0.00 \mathrm{~b}$ & $53.33 \mathrm{abc}$ & $26.67 \mathrm{c}$ & $0.00 \mathrm{~b}$ \\
\hline $\begin{array}{l}1000 \mathrm{ppm} \\
\text { IBA }\end{array}$ & 6.67 & $0.00 \mathrm{c}$ & 0.00 & $100.00 \mathrm{a}$ & $100.00 \mathrm{a}$ & $13.33 \mathrm{ab}$ & $60.00 \mathrm{ab}$ & $33.33 \mathrm{bc}$ & $6.67 \mathrm{ab}$ \\
\hline $\begin{array}{l}2000 \mathrm{ppm} \\
\text { IBA }\end{array}$ & 13.33 & $6.67 \mathrm{bc}$ & 0.00 & $86.67 \mathrm{bc}$ & $86.67 \mathrm{bc}$ & $13.33 \mathrm{ab}$ & $46.67 \mathrm{bc}$ & $33.33 \mathrm{bc}$ & $13.33 \mathrm{ab}$ \\
\hline $\begin{array}{l}4000 \mathrm{ppm} \\
\text { IBA }\end{array}$ & 6.67 & $6.67 \mathrm{bc}$ & 0.00 & $66.67 \mathrm{~d}$ & $66.67 \mathrm{~d}$ & $0.00 \mathrm{~b}$ & $46.67 \mathrm{bc}$ & $46.67 \mathrm{ab}$ & $13.33 \mathrm{ab}$ \\
\hline OSU-142 & 6.67 & $6.67 \mathrm{bc}$ & 0.00 & $66.67 \mathrm{~d}$ & $60.00 \mathrm{~d}$ & $0.00 \mathrm{~b}$ & $53.33 \mathrm{abc}$ & $33.33 \mathrm{bc}$ & $0.00 \mathrm{~b}$ \\
\hline A-18 & 6.67 & $6.67 \mathrm{bc}$ & 0.00 & $86.67 \mathrm{bc}$ & $86.67 \mathrm{bc}$ & $13.33 \mathrm{ab}$ & $53.33 \mathrm{abc}$ & $53.33 \mathrm{a}$ & $13.33 \mathrm{ab}$ \\
\hline OSU+A-18 & 6.67 & $0.00 \mathrm{c}$ & 0.00 & $80.00 \mathrm{~cd}$ & $80.00 \mathrm{~cd}$ & $6.67 \mathrm{ab}$ & $60.00 \mathrm{ab}$ & $46.67 \mathrm{ab}$ & $0.00 \mathrm{~b}$ \\
\hline $\begin{array}{l}1000 \mathrm{ppm} \\
\mathrm{IBA}+\mathrm{OSU}- \\
142\end{array}$ & 6.67 & $0.00 \mathrm{c}$ & 0.00 & $66.67 \mathrm{~d}$ & $66.67 \mathrm{~d}$ & $0.00 \mathrm{~b}$ & $46.67 \mathrm{bc}$ & $33.33 \mathrm{bc}$ & $20.00 \mathrm{a}$ \\
\hline $\begin{array}{l}2000 \mathrm{ppm} \\
\text { IBA +OSU- } \\
142\end{array}$ & 20.00 & $20.00 \mathrm{a}$ & 0.00 & $73.33 \mathrm{~cd}$ & $73.33 \mathrm{~cd}$ & $13.33 \mathrm{ab}$ & $53.33 \mathrm{abc}$ & $53.33 \mathrm{a}$ & $20.00 \mathrm{a}$ \\
\hline $\begin{array}{l}4000 \mathrm{ppm} \\
\mathrm{IBA}+\mathrm{OSU}- \\
142\end{array}$ & 13.33 & $13.33 \mathrm{ab}$ & 0.00 & $66.67 \mathrm{~d}$ & $66.67 \mathrm{~d}$ & $26.67 \mathrm{a}$ & $40.00 \mathrm{c}$ & $33.33 \mathrm{bc}$ & $20.00 \mathrm{a}$ \\
\hline $\begin{array}{l}1000 \mathrm{ppm} \\
\mathrm{IBA}+\mathrm{A}-18\end{array}$ & 6.67 & $0.00 \mathrm{c}$ & 0.00 & $66.67 \mathrm{~d}$ & $66.67 \mathrm{~d}$ & $0.00 \mathrm{~b}$ & $60.00 \mathrm{ab}$ & $53.33 \mathrm{a}$ & $20.00 \mathrm{a}$ \\
\hline $\begin{array}{l}2000 \text { ppm } \\
\mathrm{IBA}+\mathrm{A}-18\end{array}$ & 6.67 & $6.67 \mathrm{bc}$ & 0.00 & $66.67 \mathrm{~d}$ & $60.00 \mathrm{~d}$ & $0.00 \mathrm{~b}$ & $46.67 \mathrm{bc}$ & $46.67 \mathrm{ab}$ & $20.00 \mathrm{a}$ \\
\hline $\begin{array}{l}4000 \text { ppm } \\
\text { IBA +A-18 }\end{array}$ & 6.67 & $0.00 \mathrm{c}$ & 0.00 & $73.33 \mathrm{~cd}$ & $73.33 \mathrm{~cd}$ & $0.00 \mathrm{~b}$ & 66.67 a & $60.00 \mathrm{a}$ & $20.00 \mathrm{a}$ \\
\hline LSD & Ö.D. & 24.72 & Ö.D. & 22.16 & 21.09 & 25.99 & 15.57 & 15.95 & 27.47 \\
\hline
\end{tabular}


Table 2 (Continuation)

The effects of applications on the cutting rooting of trifoliate orange

\begin{tabular}{|c|c|c|c|}
\hline & Viability rate $(\%)$ & Callus formation rate $(\%)$ & Rooting rate $(\%)$ \\
\hline SOFTWOOD CUTTINGS & $8.72 \mathrm{c}$ & $5.13 \mathrm{c}$ & $0.00 \mathrm{c}$ \\
\hline SEMI-HARDWOOD CUTTINGS & $76.41 \mathrm{a}$ & $75.38 \mathrm{a}$ & $6.67 \mathrm{~b}$ \\
\hline HARDWOOD CUTTINGS & $52.82 \mathrm{~b}$ & $42.56 \mathrm{~b}$ & $12.82 \mathrm{a}$ \\
\hline LSD & 18.92 & 12.83 & 1.91 \\
\hline
\end{tabular}

\section{Conclusions}

As a result, the effects of IBA and bacterial applications on rootstocks of bitter orange and trifoliate orange citrus fruits were investigated in this study. This study mainly focuses on the effects of plant growth promoting bacteria, which are used as an alternative to steel rooting in recent years. It can be investigated in new studies whether rooting rates will increase by testing different races of these bacteria and combinations with different growth regulators.

\section{Aknowledgement}

This research was prepared from entitled "Bakteri ve IBA Uygulamalarının Bazı Turunçgil Anaçlarında Çelik Köklenmesi Üzerine Etkileri" of master of science thesis of Mustafa ÇINAR in Selçuk University.

\section{References}

Ahmad, T, Ur-Rahman H, Ahmed CH, Laghari MH (2005). Effect of culture media and growth regulators on micropropagation of peach rootstock GF 677, Pakistan Journal of Botany, 35(3), 331-338.

Antonopoulou C, Dimassi K, Therios I, Chatzissavvidis C, Tsirakoglou V (2005). Inhibitory effect of riboflavin (Vitamin $\mathrm{B}_{2}$ ) on the in vitro rooting and nutrient concentration of explants of peach rootstock GF 677 (Prunus amygdalus $x$ P. persica), Scientia Horticulturae, 106, 268-272.

Arıkan Ş, İpek M, Eşitken A, Prrlak L (2015). Effects of IBA and Plant Growth Promoting Rhizobacteria (PGPR) on Rooting and Root Growth of Myrtle (Myrtus communis L.) Stem Cuttings. Environmentally Friendly Agriculture and Forestry for Future Generations, XXXVI CIOSTA \& CIGR Section V Conference, pp: 42-45.

Bassil NV, Proebsting WM, Moore LW, Lightfoot DA JH (1991). Propagation of hazelnut stem cuttings using Agrobacterium rhizogenes, HortScience, 26 (8), 1058-1060.

Bhusal RC, Mizutani F, Rutto KL (2003). Effects of juvenility on the rooting of trifoliate orange (Poncirus trifoliata Raf.) stem cuttings. J. Jpn. Soc. Hort. Sci. $72,42-45$.
Cooper WC (1935). Hormones in relation to root formation on stem cuttings. Plant Physiol., 10, 789794.

De Klerk G-J, Ter Brugge J, Marinova S (1997). Effectiveness of indoleacetic acid, indolebutyric acid and naphthaleneacetic acid during adventitious root formation in vitro in Malus 'Jork 9', Plant Cell. Tiss. Org. 49: 39-44.

Ercişli S, Eşitken A, Cangi R, Şahin F (2003). Adventitious root formation of kiwifruit in relation to sampling date, IBA and Agrobacterium rubi inoculation. Plant Growth Regulation 41: 133-137.

Ercişli S, Eşitken A, Şahin F (2004). Exogenous IBA and inoculation with Agrobacterium rubi stimulate adventitious root formation on hardwood stem cuttings of two rose genotypes. HortScience 39(3):533-534.

Erturk Y, Ercisli S, Haznedar A, Cakmakci R (2011). Effects of plant growth promoting rhizobacteria (PGPR) on rooting and root growth of kiwifruit (Actinidia deliciosa) stem cuttings. Biol Res 43: 9198.

FAO (2019). www.fao.org (Access date, 01.02.2019).

Gülcan R (1991). Meyve ağaçlarında anaç 1slahı, Türkiye 1. Fidancilık Sempozyumu, 185-193.

Habermann G, Alvarez RDF, Modesto JC, Fortes AMD, Rodrigues JD, Ono EO (2006). Rooting of healthy and CVC affected 'Valencia' sweet orange stem cuttings through the use of plant regulators. Braz. Arch. Biol. Technol. 49, 29-36.

Hartmann, H.T., Kester, D.E. and Davies, F.T. Jr., 1990, Plant Propagation, Principles and practices. Prentice-Hall, Inc. New Jersey, 647 p.

Hatta M, Beyl CA, Garton S, Diner AM (1996). Induction of roots on jujube softwood cuttings using $\mathrm{Ag}$ robacterium rhizogenus. Journal of Hort. Sci., 71(6):881-886.

Jacob M, Handam I (1992). Use of benefical bacteria for Pelargonium zonale. Gartenbaumagazin. 1(3):105-107.

Kınık E, Çelikel FG (2017). Bakteri ve oksin uygulamalarının kuşburnu bitkisinin çelikle çoğaltılması üzerine etkileri, Türk Tarım Gıda Bilim ve Teknolojisi Dergisi, 5 (13), 1714-1719.

Larraburu EE, Carletti SM, Rodríguez Cáceres EA, Llorente BE (2007). Micropropagation of photinia 
employing rhizobacteria to promote root development, Plant Cell Reports, 26 (6), 711-7.

Mendilcioğlu K (1999). Subtropik İklim Meyveleri (Turunçgiller), Ege Üniv. Ziraat Fak. Yay. Ders Notlar1: 9/5.

Nagarajan P, Ratha NV, Kandasamye D, Oblisami G, Jayaraj S (1989). Effect of combined inoculation of Azospirillum brasilense and Glomus fasciculatum on mullbery. Madras Agricultural Journal. 76(11):601-605.

Pirlak L, Baykal Y (2009). Effect of IBA and Bacteria (Agrobacterium rubi and Bacillus OSU 142) on the Rooting of M9 Apple Rootstock Cuttings. $1^{\text {st }}$ International Syposium on Sustainable Development, pp. 129-134, Sarajevo.

Rom RC (1987). Roots, Rootstocks for Fruit Cropps, Rom, C.R. and Carlson, R.F. (eds). A WileyIntersience Publ., U.S.A., pp 107-144.

Rugini E, Fedelli E (1990). Olive (Olea europaea L.) as an oilseed crop. Ed. J.P.S. Bajaj, Biotechnology in Agriculture and Forestry, Vol. 10: Legumes and oilseed crops. I.Springer- verlag Berlin, Heiderberg.
Sarmast MK, Salehi H, Khosh-Khui M (2012). In vitro rooting of Araucaria excelsa R. BR. var. Glauca using Agrobacterium rhizogenes, Journal of Central European Agriculture, 13(1), 123-130.

Singh Z, Sandhu AS, Dhillon BS (1988). Rooting and sprouting of stem cuttings of Citrus jambhiri in response to IBA and cyclophosphamide. Acta Hort. 227, 145-149.

Teixeira DA, Alfenas AC, Mafia RG, Ferreira EM, De Siqueira L, Maffia LA, Mounteer AH (2007). Rhizobacterial promotion of eucalypt rooting and growth, Brazilian Journal of Microbiology, 38: 118123.

TUIK (2019). www.tuik.gov.tr (Access date, 01.05.2019),

Uzun A, Seday Ü (2011). Farklı IBA dozlarının farklı turunçgil anaçlarının odun çeliklerinin köklenmeleri üzerine etkileri. Erciyes Üniv. Fen Bil. Ens. Der. 212-216.

Webster AD, Looney NE (1996). Cherries. Crop Physiology, Production and Uses. CAB International, Wallingford $513 \mathrm{pp}$. 